\title{
Early to Mid-Career Women Managers : Experiences of Gendered Age, Care and Work
}

\section{McKie, Linda}

\section{Edward Elgar}

2018-05-25

McKie, L \& Jyrkinen, M 2018 , Early to Mid-Career Women Managers : Experiences of Gendered Age, Care and Work . in A M Broadbridge \& S L Fielden (eds), Research Handbook of Diversity and Careers : New Horizons in Management . Edward Elgar, pp. 44-59 . https://doi.org/10.4337/9781785365607.00009

http://hdl.handle.net/10138/268049

https://doi.org/10.4337/9781785365607.00009

unspecified

acceptedVersion

Downloaded from Helda, University of Helsinki institutional repository.

This is an electronic reprint of the original article.

This reprint may differ from the original in pagination and typographic detail.

Please cite the original version. 


\section{Chapter 2}

\section{Early to Mid-Career Women Managers: Experiences of Gendered Age Care and Work}

\section{Linda McKie and Marjut Jyrkinen}

In this chapter we consider the impact of age and gender in the working life and career development of early to mid-career women managers working in Finland and Scotland, UK. The participants were recruited from a range of organisations, many of which continue to be gender segregated. In Scotland, women were recruited from the traditionally female dominated careers of human resources, education and health. By contrast, in Finland the women recruited were working in industries dominated by male workers such as engineering and telecommunications. Our study builds on an interpretive approach which allows the analysis of the intersections of gender and age in the experiences of the interviewed women managers in their early ages and career stages.

The research reported in this chapter offers two contributions to debates on diversity and careers. First, the research was conducted across two current European Union (EU) member states and thereby they need to adhere to EU directives and strategies on equality, gender and the workplace. Yet women reported strikingly similar experiences of workplace opportunities, challenges and discrimination. In the 2015 Global Gender Gap Report (World Economic Forum, 2015), Finland is ranked third and the UK 18th. Even with Finland achieving this high ranking, women are experiencing challenges in the workplace which can restrict career achievements. Second, despite the plethora of legislation and strategies on working life and gender equality across several decades, participants reported having faced discriminatory questions in recruitment interviews and challenges in their supervision of coworkers, as well as having to reconcile work, family, domestic and care responsibilities. Thus 
in our data, age and gender intersected to position early to mid-career women as potentially 'less committed' to their careers, and perceived by many others as different to the assumed norms of everyday workplace practices. The challenge to their credibility as managers was ever present, and evident across the various sectors and organisations. Further, discriminatory actions were said to be evident in workplace relations and conversations amongst men and women colleagues.

In summary, our analysis suggests that both direct and indirect discrimination intersects across these EU member states, various sectors and women's ages. Younger women managers are positioned as potentially problematic. The diversity in workplaces offered by the growth in younger women managers, seeking longer-term career development, is challenged by some co-workers and superiors. In the final section we consider whether or not diversity in terms of age and gender can be embraced in management careers, or are those who differ from the masculinist model of manager likely to experience discriminatory practices for some time to come?

\section{Finland and Scotland, UK: A Contrast of Contexts}

Finland and Scotland have a number of geographical, social and political parallels. Both countries have a similar population size (over 5 million) with a concentration of around 70 per cent of the population in a core urbanised area of each country: in Finland, the Helsinki Metropolitan Area and the cities in southern-mid Finland; in Scotland, the 'Central Belt' that runs between Edinburgh and Glasgow. The governments of both countries are negotiating a period in which populations are ageing, and families and relationships are dynamic in relation to divorce, co-habitation, same sex partnerships, and family re-formation as well as a growth in solo living. These changes pose particular issues for women who are expected to work, and who themselves wish to work, throughout adult life and into their sixties. The question of 
planning for careers and, in the longer term, retirement must also address the continued gender pay gap. The most recent comparable figures are from 2012: on average the gap is 16.4 per cent in the EU, 19.4 per cent in Finland and 19.1 per cent in the UK (European Commission, 2012). Thus the post retirement income and pensions of many women remain lower than those of equivalent men (ibid.).

Women make up about half of the workforce both in Finland and in Scotland. 42 per cent of women in Scotland work part-time, but in marked contrast, 82 per cent work full-time in Finland (Close the Gap, 2015; Statistics Finland, 2014). This notable contrast in part- or full-time working is thought to be due to the Finnish provision of universal day care and a parental leave system that enables either of the parents to stay at home until their child is three years old and the other parent to work during this time. However, only 10 per cent of parental leave is used by fathers. Finnish women's full-time work is also based upon history and the evolution of the economy and welfare system in the last 70 years. Women's participation in working life formed the basis to policies and services supported and promoted by the high educational attainment of women, an individual-based taxation system and women's extensive engagement in labour unions ( 55 per cent of all members) (LammiTaskula, 2004; Saari, 2016; Salmi, Lammi-Taskula and Narvi, 2009).

There are a number of other obvious contrasts in approaches to gender equality and issues of work and well-being. Finland and the UK have differing economies, including the UK being outside both the Euro currency and the Schengen agreement on movement inside specific EU member states. Differences will increase following the planned departure of the UK from the EU. This could also result in changes to women's workplace rights, although as we write the implications of what has become termed Brexit, remains unclear. Other contrasts are also notable, particularly the greater regulation of workplaces in Finland and differences in health and safety, and in equality and diversity. For instance, organisations employing 30 
or more workers in Finland, must, by law, have an equality and equity plan(s) in place (Laki naisten ja miesten tasa-arvosta, 1986/2014) whilst this is not the case in Scotland.

Finland's image as a relatively gender-equal society cloaks high levels of gender segregation in its labour market in which, as in Scotland, women are over-represented in lower-paid caring and service sectors and precarean careers. The Finnish labour market has been ranked as the fourth most gender segregated in the EU-27 (Bettio and Verashchagina, 2009), with women dominating public sector jobs and men the private and public sectors in construction work, logistics and traditional manufacturing industries. Similar trends exist in Scotland, but are not as marked: the UK was 24th in this ranking. Analysis drawn on the basis of the Fourth European Working Conditions Survey, of managers women comprise 36 per cent in Finland and 38 per cent in the UK, the average in the EU being 33 per cent (LylyYrjänäinen and Fernández Macías, 2009). By 2015 the Sixth European Working Conditions Survey (Eurofound, 2015) reported that across the 35 countries included in the survey, the proportion of employees who reported having a female supervisor had increased from 24 per cent in 2000 to 33 per cent in 2015 . However, a high degree of gender segregation persists with half of all female employees having a female supervisor, compared to 15 per cent of men.

\section{Age and Careers}

Age discrimination is illegal in both countries and working life and careers are also changing rapidly as workforces grow older. Profound societal changes, such as globalisation of business and work, the growth of digital and automated work as well as the drive to entrepreneurship also lead to notable and ongoing changes. These impact on how we understand careers: so called traditional careers - linear, upward-going, uninterrupted and 
life-long are decreasingly evident (see Hall, 2002). The prototype of the uninterrupted, hierarchical career path, most often assumed to be that of the heterosexual, male, mostly white, mid/upper-class manager, offers a norm which persists in everyday images and profiles of managers (Jyrkinen, 2014; Jyrkinen and McKie, 2012). Women's careers in management face more hurdles and interruptions and often differ from those of men (Burke, 2007; Kirchmeyer, 1998; Mainiero and Sullivan, 2005). Childbearing, care-giving responsibilities and the day to day emotional labour involved in work and at home are gendered (Hopkins and O’Neil, 2007; McKie et al., 2008). So too are roles in the workplace with women over-represented in certain arenas of management work, for instance human resources, and in everyday practices such as colleague support and team-building which are crucial for all current and future work (European Commission's Expert Group on Gender and Employment, 2009).

There are many educational and personal features and social categories that influence recruitment into, and career development in, management (Dessler, 2011; Konrad, 2007). Inclusion or exclusion is often not formally based on, for instance, 'suitable' or 'unsuitable' age or gender because of the anti-discrimination laws in most countries. Instead, exclusion from career development often takes place through more subtle and hidden processes of discrimination (Husu, 2001; Lämsä and Sintonen, 2001). Inclusion may, consciously or unconsciously, be actualised through complex social and cultural relationships, networks, comradeship and homosociality, where preferences for similarity overcome formal competence criteria (e.g. Hearn, 2015; Hearn and Parkin, 1995). Being a woman can still be characterised as a major obstacle to career advancement into top leadership and management positions in many organisations (Hearn et al., 2008; Liff and Ward, 2001), and the processes of gendering further intersect with age factors. Senior managerial positions are traditionally held by older men, and many women's careers stagnate in early to middle years of working 
life due to a range of factors, including career breaks limiting experience and training, presumptions about energy and the menopause, and the strongly held notion of masculinities and leadership (Hutchings and Michailova, 2014).

With the growth of women in managerial careers, especially in mid-level roles, conceptualisation(s) of careers have evolved. Concepts to aid the analysis of women's careers include:

- The kaleidoscopic career which refers to the multidimensional, cyclic nature of a woman's life and career as challenge, balance and authenticity across the life-span (Mainiero and Sullivan, 2006);

- The patchwork career which is defined as collating different tasks within and across a career and weaving together work, lifestyle, and goals towards self-fulfilment (see Blossfeld, Mills and Bernandi, 2006; Halrynjo, 2009)

- 'Careerscapes' (McKie, Biese and Jyrkinen, 2013) to describe the changing and nonlinear processes of career and care through identifying and exploring the myriad temporal and spatial dimensions across the lifecourse.

All these offer ways of exploring change over the years and presume women are buffeted by gendered practices, socio-economic changes in family and working life, and that struggles to achieve equality remain.

\section{The Study}

The data here are drawn from eight women involved in a total of 25 interviews and four focus groups, which included 22 women, all of whom had a job title which included 'manager'. The eight interviews were chosen to reflect key themes emerging in both countries. Interviewees were recruited firstly, through approaching two organisations for professional 
women (not named to preserve anonymity) which were active in both countries. The recruitment criteria, applied in both countries, were that participants held a managerial position in a business or a third sector organisation, and that they were aged 30 or over. We adopted this age criterion to ensure women had some years of experience of working life to draw upon in interviews.

\section{INSERT TABLE 2.1 ABOUT HERE}

These participants ranged in age from early 30 s to late 40s and all had college level qualifications or above. Five of the women had children, with seven of the eight married or co-habiting. In Scotland women were working in traditionally female sectors (education, customer services) and by contrast in Finland in less traditional sectors including technology, media and engineering.

All interviews were tape-recorded, translated if necessary and transcribed, and research diaries and notes on the company and environment in which the interview took place. Interviews were structured around the topics of career phases; organisational policies and relationships with work colleagues; and mentors and networks. These themes in the interview schedule derived from the vast body of research on women in management, while taking into account the relative paucity of attention paid to the impact of gender, age and gendered ageism on women's managerial careers (Acker, 2006; Calasanti, 2004; Itzin and Phillipson, 1995). The schedule was revised following piloting. Ethical issues were considered throughout the research (British Sociological Association, 2002; Finnish Advisory Board on Research Integrity, 2012). Many interviewees reported that they had never spoken comprehensively about gender, work and care issues to someone who was not a partner, 
family member or colleague, and found the topics both sensitive and daunting. In the following sections we present data to emerge from three major themes, namely, age and gendered recruitment and everyday working; care and careers; and working towards and empowering age. Pseudonyms are used for all interviewees.

\section{Age, Gendered Recruitment Practices and Career Stage}

Discrimination on the basis of the potential to childbear and consequently the need for maternity leave remains one of most persistent dimensions of gender discrimination, in spite of legislation in the EU and regardless of national laws, return-to-work guarantees, taxation and welfare support for child care. Beatrice, who is in a senior position in a Finnish company, described how her pregnancy was taken badly by several immediate colleagues and her superior. Early on it was rumoured that no one would replace her, and that on her return to work, she might end up in another - potentially lower - position. It was notable that she struggled to gain clarity on the future despite asking her superior, HR, and colleagues on several occasions. Beatrice confronted her superior, and this generated a lot of stress. The conversation resulted in demands, claims, counter-claims and even threats. She succeeded in her contention that she should return to the same post, and was eventually able to do so after her maternity leave. She reflected on these experiences: 'It amazed me that I am really the only and first woman manager at this [middle] level who was going on maternity leave. It seems that most [women] are promoted only after having children... they did not have any section managers in fertile and birth-giving years before my arrival' (Beatrice, 39, Finland).

Celeste, who has worked in marketing and media sectors, spoke about how companies expect on the one hand 'young looks', but on the other, 'more experience' from their contractors. 'When you are advising companies on how they got their sales into this mess 
[economic difficulties] and how are you going to get them out of problems, they don't like to hear that from a young person too much' (Celeste, 43, Scotland). All too often, women in their early career phases received comments about their lack of experience combined with infantilising comments, such as being referred to as 'girl', 'love' or 'honey'. 'Girling' is to call adult women 'girls' and to treat them in a patronising and infantilising ways in work contexts (Martin, 2006).

There were many instances of gendered ageism that young women had encountered in their careers in both Finland and Scotland. Alexandra discussed the recruitment process of the company:

So the environment wasn't very conducive towards women, but [instead] there was also an awful lot of direct and indirect discrimination. So when I was interviewed for the job, somebody asked me 'How would you cope with - as I was to have a lot of functions involved in corporate hospitality - a man who made a pass at you to get a business deal'? It is quite difficult to answer that, but of course the response should have been, you know, you [should be] asking prospective male [business] candidates. (Alexandra, 48, Scotland)

Many women asserted that to be a young women in a management position caused confusion amongst some colleagues, subordinates and clients:

In a company reorganisation... a couple of men aged 57 years were moved to be under my supervision, and at the same time they were dropped from the executive group. It caused some friction when I came along as a younger woman in her $40 \mathrm{~s}$, mid 
career, who was now their boss. There was chauvinistic talk and other kinds of stuff, although they did not directly confront me but of course I knew about it. (Tina, 45, Finland)

Also Alice discussed her experiences of how (young) age and gender intersected in her managerial career, both in work with clients and in business to business contexts. Particular issues arise from not been taken seriously. Alice stated: 'You are not necessarily taken seriously, because you are a young woman. Sometimes it is just because you are young, sometimes it is because you are not a man and sometimes it is both. ... But there are definitely such situations where you are not taken seriously' (Alice, 35, Scotland).

Women had encountered many instances of the use of sexist language. They described trying to avoid taking openly discriminating comments 'too seriously', but aimed to cope with those encounters through other strategies such as avoidance:

Then I had this experience [in large multinational company, (MNC)] where there were chauvinistic comments from all levels, including the CEO. Those did not however impact on my everyday life. And the CEO did not stay in his position for long but was replaced by a [country] man who was very supportive on equality issues. That [area of work] was very male, so you can just imagine that woman's position is not an easy one. On the other hand, women brought new perspectives ... (Viola, 44, Finland)

This latter part of the extract is interesting, as it reflects the idea of gender equality as a liberal feminist project with a focus upon the women and less so on the context and structures in which she works and lives. Thus, women can be included in the workplace and even 
achieve leadership, whilst gendered structures and practices remain relatively intact. In fact, Viola highlighted a positive atmosphere amongst young women and men, as well as social happenings and get-togethers - these activities and networks seemed to compensate or balance the chauvinistic comments in other business contexts. Viola also highlighted how young age and looks could also be a positive factor for her as she has been noticed as different, as a non-man: 'One could also interpret that [in male-dominated areas] being a woman has had an impact, as I have differed from others. There have been incidents where I have been told directly, in this position there has never before been a woman' (Viola, 44, Finland). Being the first woman and at an early to mid stage of her career could present challenges for the female post holder and employees.

Viola's narrative on her career in the MNC supports early research findings on token positions (Kanter, 1977). Here, a young woman was under surveillance and gaze by otherwise male-dominated management and leadership. Token positions can sometimes include positive elements, although also recent research suggests that often the token individual is understood to represent 'the whole gender' (Ryan and Haslam, 2007). Responsibility for 'all women', equality and women's issues are often laid on the shoulders of token women managers, with some of our interviewees querying why senior women did not go out of their way to help them (Hutchings and Michailova, 2014).

\section{Care and Career}

One major area of discrimination in young women managers' careers is in issues related to gendered care. The impact of care duties on career were discussed by Susan, whose elderly parent had a serious seizure only a few days before the interview. Susan had continued working, but brought up her own mixed feelings about how to take time off work for visits to hospital: 
Perhaps this is a 'good' woman or girl syndrome, as I have a somewhat bad conscience now when I need to leave work earlier in order to get to the intensive care unit in time to stay for 15 minutes, the time that is allowed per day. ...It has crossed my mind how people might react to this [leaving earlier], but I have not wanted to talk about the situation in public as I do not have the strength to comment much on the situation day by day. (Susan, 33, Finland)

Susan's hesitance was connected to company policies which were unclear about flexible and distance work: 'There is a mention of the possibility in the HR handbook. However, I have a strong feeling that there is no encouragement for this in practice' (Susan, 33, Finland).

In the Scottish sample, issues about care and careers were also brought up in many interviews. Alice, who did not have children, discussed how care responsibilities for young children and elderly people are viewed. In the business sector in which Alice works, some of the work meetings with clients need to take place in the evenings:

I think there needs to be more encouragement of work-life balance especially for people who have children. But not just for people who have children. ... My colleagues who have children prefer meetings earlier in the day, which on one hand I agree with as they have family commitments, I don't have. But on another hand I think it can be quite annoying. I don't have children but this doesn't necessarily mean I would like to be working to 7 or $8 \mathrm{pm}$. (Alice, 35 , Scotland)

Alice continued that the focus of policies on care is often on families with small children, and there is a lack of understanding of care for other significant persons in need of help: 
There are many more day-care [possibilities] and help for people with children... Increasingly people have to look after their parents or older relatives. And that's as an equal responsibility to people who have their own [nuclear] families. .. It is considered much more appropriate to be flexible if you have children I suppose than if you have elderly [parents]. And I think it is part of ageism in society. (Alice, 35, Scotland)

In many of the interviews, gender in the context of care responsibilities meant implicitly women. Men did not 'exist', in particular when the discussion was on elder care. However, some women pondered gender equality at work as regards care of children. Viola reflected on the responsibilities and impact on care duties between spouses and at workplaces as follows:

When the children were small it was naturally the toughest time for making equality happen so that the responsibilities for the children were equal between us both. In addition, a challenge at work is that the expectation of the main responsibility for small children is on women. From women one always knows if you have children, but from men this is not so. (Viola, 44, Finland, emphasis ours).

The above quote from Viola about the 'obviousness' of women to have the main responsibility of children is remarkable. Men have children too, but that does not come up necessarily in everyday talk and nor does it impact on their careers. Men in top management tend to have more children than women in similar positions (e.g. Hearn et al., 2008; 
Hutchings and Michailova, 2014). Claudia was of the opinion that there needs to be more effective ways to share the care responsibilities in order to enable women's career progress:

.... we should be pushing for partners to do more and to take equal responsibilities so that you get the two partners devoting [time to care] ..... sacrificing less on both sides of the parenting or care partnership. (Claudia, 47, Scotland)

\section{An Empowering Age?}

As we explored interviewees' views on 'the best age' for women managers, many were of the opinion that for them, the best time is now or is to come, and none of the women considered that it had been in the past. Tina commented on age/ageing issues as follows:

Older generations are of the opinion that it is possible to retire already at 55 years of age, and 58 years was more like a rule than exception. ... But we will be here [continuing to work] for a long time. ... I think it [the best age for women managers] is something around 40s and 50s, when you have gained enough years [hence experience] that you can, and do dare, express your opinions and there is no need to be modest. On the other hand one is then not too old to learn new things [laughs] and [your] children are old enough that there is time for other things than changing nappies. (Tina, 45, Finland)

Most women had encountered either open or more subtle discrimination on the basis of age and/or gender. In many cases these incidences intersected, and gendered ageism took place also at a young age and in the early stages of careers. The women interviewed, however, were positive about their futures. For instance, Celeste described a recruitment process through 
which a younger and less competent man was appointed instead of her. Although Celeste was upset about this, and she interpreted this as unfair treatment, she still thought that this unpleasant experience had left her stronger and that 'the best job is ahead':

The best job is ahead. And there have been stepping stones on the way... without those I am not going to get a big job....But I know that if I get past this anger that I feel at the moment I will come to a more peaceful place and then I would like to evolve and I think that [the big] job is ahead of me! (Celeste, 43, Scotland)

There were also empowering elements as regards networking by women at different ages and career stages. Alice highlighted how this can be really valuable: 'And what I really enjoy is having access to older women in a network... They've got experience of balancing their work and their life!' (Alice, 35, Scotland). It was also evident that through participating in our focus groups women networked and shared experiences on how to deal with indirect and direct discrimination. Further, when the authors held sessions to launch a briefing paper based upon the findings of the study some two years after the end of the study, women spoke warmly of the ways in which they connected and shared support. Many stayed long after the event and several organised to meet up at a later date. This is a positive and unintended outcome of our research and one which reflects the self-selecting nature of the participants; they are likely to explore career options with researchers and peers.

\section{Conclusions}

Our analysis demonstrates how persistent direct and indirect, overt and covert, discrimination is across a range of workplaces and sectors in both Finland and Scotland, UK. Thus, regardless of equality legislation and support to combine caring and working, women 
continue to struggle to be taken seriously and progress their careers. Our data consisted of well-educated women in the earlier to mid stages of their careers, and it might be expected they would not experience direct discrimination, given that there has been legislation outlawing direct discrimination for over 40 years. Research suggests that the current pace of change means that equality in terms of pay, seniority and security, could take a century or more to be achieved (Loretto and Vickerstaff, 2013). We can only conclude that whilst workforces are increasingly diverse, and participation rates in management careers are rising among younger women, hurdles remain in achieving promotion (Grant Thornton International Business Report, 2014).

It is evident that there is a dissonance between what governments and employers suggest to be possible in equality and in women's everyday experiences. Often the recommendation is for more policies, training and awareness-raising but might it be time to focus on management and leadership? It is not unusual that the role of HR is limited in strategic leadership, and instead covers only participation and training in equality issues, as well as managing complaints (Wells, 2013). Our study suggests that the day-to-day and longer-term experiences of early to mid-career women are ignored, taken for granted or considered to be dealt with through HR policies. Transparency in pay and transparency in terms of the issues presenting challenges for women must be the way forward. Mothers, parents and citizens generate the next generation, who will pay for our pensions, and many also care for elders at one and the same time. Unpaid care work, along with the intergenerational 'gift' of future workers, is rarely discussed and yet imperative to our futures. Thus we draw our chapter to a close on a philosophical point but one relevant across the world. 
If we return to the conceptual frameworks for analyzing careers, noted earlier in the chapter, we can conclude that they offer theoretical potential. Women spoke of the multidimensional and cyclic nature of working life - the kaleidoscopic career - and of how they 'stitched' experiences together or dropped sections of their career quilt (Mainiero and Sullivan, 2006; Halrynjo, 2009). Across all the narratives experiences care and caring over the lifecourse was intimately meshed with careers. Women reflected on previous, current and anticipated 'careerscapes' (McKie et al., 2013). The terrain of the career remains largely devoid of the realities of being female and moving from early to late career through cycles of relationships, family changes and the every constant need for care in human flourishing both in and out of the workplace.

In conclusion, many organisations profess to be working towards diversity in the workforce. Nevertheless, women were regularly dealing with direct and indirect discrimination, with age and gender raised as issues from being a woman supervising men; to potentially becoming pregnant; taking maternity leave; becoming a carer; and reconciling domestic, family and working life. However, without their many dimensions of work, paid and unpaid, we would live in a poorer world.

\section{Acknowledgement}

This research has been enabled by the support by the Academy of Finland (AF). The article has been produced within the WeAll - Economically and Socially Sustainable Future Working Life (Project No. 292883), funded by the Strategic Research Council based at the $\mathrm{AF}$. 
Table 2.1: Key Characteristics of Women Interviewees

\begin{tabular}{|c|c|c|c|c|c|c|}
\hline Pseudonym & $\begin{array}{l}\text { Current } \\
\text { Work Sector }\end{array}$ & Age & Education & $\begin{array}{l}\text { Partnership } \\
\text { Status }\end{array}$ & Children & Location \\
\hline Susan & Technology & 33 & $\begin{array}{l}\text { College and } \\
\text { Business } \\
\text { Administration }\end{array}$ & Co-habiting & None & Finland \\
\hline Beatrice & $\begin{array}{l}\text { Insurance/ } \\
\text { Business }\end{array}$ & 39 & University & Married & 2 children & Finland \\
\hline Viola & Technology & 44 & University & Married & 2 children & Finland \\
\hline Tina & Technology & 45 & University & Married & 2 children & Finland \\
\hline Alice & Accounting & 35 & University & Married & None & Scotland \\
\hline Celeste & $\begin{array}{l}\text { Education/ } \\
\text { Skills } \\
\text { development } \\
\text { business }\end{array}$ & 43 & $\begin{array}{l}\text { College and } \\
\text { other studies }\end{array}$ & $\begin{array}{l}\text { Single/ } \\
\text { divorced }\end{array}$ & None & Scotland \\
\hline Claudia & $\begin{array}{l}\text { Media } \\
\text { consulting/ } \\
\text { Marketing }\end{array}$ & 47 & University & Married & 3 children & Scotland \\
\hline Alexandra & $\begin{array}{l}\text { Construction/ } \\
\text { Technology }\end{array}$ & 48 & University & Married & 3 children & Scotland \\
\hline
\end{tabular}




\section{References}

Acker, J. (2006), 'Inequality regimes: Gender, class, and race in organizations', Gender \& Society, 20, 441-464.

Bettio, F. and Verashchagina, A. (2009), Gender Segregation in the Labour Market. Root causes, implications and policy responses in the EU. Luxemburg: Publications office of the European Union.

Blossfeld, H.P., M. Mills and F. Bernandi (2006), Globalisation, Uncertainty and Men's Careers. An International Comparison, Cheltenham: UK and Northampton, MA, USA Edward Elgar Publishing.

British Sociological Association (2002) Statement of Ethical Practice for the British Sociological Association, accessed 18 November 2016 at https://www.britsoc.co.uk/equalitydiversity/statement-of-ethical-practice/.

Burke, R.J. (2007), 'Career Development of Managerial Women: Attracting and Managing Talent', in D. Bilimoria and S.K. Piderit (eds.) Handbook on Women in Business and Management, Cheltenham, UK and Northampton, MA, USA: Edward Elgar Publishing Limited, pp. 109-131.

Calasanti, T. (2005), 'Ageism, gravity, and gender: experiences of ageing bodies' Generations, 29(3), 8-12. 
Close the Gap (2015), 'The Pay Gap in Scotland', accessed 11 August 2016 at www.closethegap.org.uk/content/gap-statistics/

Dessler, G. (2011), Human Resource Management: Global Edition, Boston, USA: Pearson.

Eurofound (2015), First Findings: Sixth European Working Conditions Survey, Brussels: EU Publications Office.

European Commission (2012), 'Gender Pay Gap', accessed 18 November 2016 at ec.europa.eu/justice/gender-equality/gender-pay-gap/index_en.htm

European Commission's Expert Group on Gender and Employment (2009) Gender segregation in the labour market. Root causes, implications and policy responses in the EU Brussels: Directorate-General for Employment, Social Affairs and Equal Opportunities.

Finnish Advisory Board on Research Integrity (2012) Responsible conduct of research and procedures for handling allegations of misconduct in Finland, accessed 18.10.2016 at http://www.tenk.fi/en/responsible-conduct-research-guidelines/responsible-conduct-research.

Grant Thornton International Business Report (2014), 'Women in Senior Management: Still Not Enough', accessed 17 October 2016 at http://www.grantthornton.global/en/insights/articles/women-in-business-2013/ Hall, D.T. (2002), Careers In and Out of Organisations, Thousand Oaks, CA, USA: Sage. 
Halrynjo, S. (2009), 'Men's work-life conflict: career, care and self-realization: patterns and privileges and dilemmas', Gender, Work and Organization, 16 (1), 98-125.

Hearn, J. (2015), Men of the World: Genders, Globalizations, Transnational Times. London: Sage.

Hearn, J., M. Jyrkinen, R. Piekkari, and E. Oinonen (2008), 'Women home and away: transnational work and gender relations', Journal of Business Ethics, Special Issue: Women, globalisation and global management, 83(1), 41-54.

Hearn, J. and W. Parkin (1995), 'Sex' at 'Work': The Power and Paradox of Organisation Sexuality, New York: St. Martin's Press.

Hopkins, M.M. and D.A. O’Neil (2007), ‘Women and Success: Dilemmas and Opportunities', in D. Bilimoria and S.K. Piderit (eds.) Handbook on Women in Business and Management. Cheltenham, UK and Northampton, MA, USA: Edward Elgar Publishing Limited, pp. 132-153.

Husu, L. (2001), Sexism, Support and Survival in Academia: Academic Women and Hidden Discrimination in Finland. Helsinki: Department of Social Psychology, University of Helsinki.

Hutchings, K. and S. Michailova (2014), Research Handbook on Women in International Management, Cheltenham, UK and Northampton, MA, USA: Edward Elgar Publishing. 
Itzin, C. and C. Phillipson (1995), 'Gendered ageism: a double jeopardy for women in organizations' in: Itzin, C. and C. Phillipson (eds), Gender, Culture and Organizational Change: Putting Theory into Practice. London: Routledge, pp. 84-94.

Jyrkinen, M. (2014), 'Women managers, careers and gendered ageism', Scandinavian Journal of Management. An International Journal, 30 (2), 175-185.

Jyrkinen, M. and L. McKie. (2012), 'Gender, age and ageism: experiences of women managers in two EU countries', Work, Employment and Society, 26: 61-77.

Kanter, R.M. (1977), Men and Women of the Corporation. New York: Basic Books.

Kirchmeyer, C. (1998), 'Determinants of managerial career success: evidence and explanation of male/female differences', Journal of Management, 24: 673-692.

Konrad, A. (2007), 'The effectiveness of human resource management practices for promoting women's careers', in D. Bilimoria and S.K. Piderit (eds.) Handbook on Women in Business and Management, Cheltenham, UK and Northampton. MA. USA: Edward Elgar Publishing, pp. 254-276.

Laki naisten ja miesten välisestä tasa-arvosta [Equality Act] (1986/2014).

Lammi-Taskula, J. (2004), ‘Äidit työmarkkinoilla - kahden kerroksen väkeä?’ [Mothers on work-markets - two level population?], Yhteiskuntapolitiikka, 69 (2), 202-206. 
Lämsä, A-M and T. Sintonen. (2001), 'A discursive approach to understanding women leaders in working life', Journal of Business Ethics, 34 (3), 255-267.

Liff, S. and K. Ward (2001), 'Distorted views through the glass ceiling: the construction of women's understandings of promotion and senior management position', Gender, Work and Organization, 8 (1), 19-36.

Loretto, W. and Vickerstaff, S. (2013) The domestic and gendered context for retirement, Human Relations, 66 (1), 65-86.

McKie, L., I. Biese and M. Jyrkinen (2013),'”The best time is now!": The temporal and spatial dynamics of women opting in to self-employment', Gender Work and Organization Special Issue, Frayed careers: rhythms of working lives, 20 (2), 184-196.

McKie, L., J. Hearn., S. Bowlby, G. Hogg and A Smith (2008), Organisations Carescapes: Researching Organisations, Work and Care, Swedish Published Papers, Helsinki, Finland: Swedish School of Economics.

Mainiero, L.A. and S.E. Sullivan (2005) 'Kaleidoscope careers: an alternative explanation for the opt-out revolution, Academy of Management Executive, 19 (1), 106-123.

Martin, Y.P. (2006), 'Practicing gender at work: further thoughts on reflectivity', Gender, Work and Organization, 13 (3), 254-276. 
Ryan M. K. and Haslam S. A. (2007). The glass cliff: Exploring the dynamics surround the appointment of women to precarious leadership positions. Academy of Management Review, $32,549-572$

Saari, M. (2016) Samapalkkaisuus - neuvoteltu oikeus. Naisten ja miesten palkkaeriarvoisuus poliittisenaja oikeudellisena kysymyksenä korporatistisessa Suomessa [Equal pay - a negotiated right. Unequal pay between women and men as a political and judicial problem in corporatist Finland]. Valtiotieteellisen tiedekunnan julkaisuja 25. University of Helsinki.

Salmi, M., Lammi-Taskula, J. and Närvi, J. (2009) Perhevapaat ja työelämän tasa-arvo [Parental leaves and work-life equality]. Työ- ja elinkeinoministeriön julkaisuja 24/2009. Edita Publishing Oy.

Scottish Government (2012), A qualifications and continuous professional development framework for the career development workforce in Scotland, accessed 7 September 2016 at Www.scotland.gov.uk/Publications/2012/07/5300/downloads.

Statistics Finland (2014), Women and Men in Finland. Edita, Helsinki.

Wells, A. (2013) What is HR Leadership? A Twenty-First Century Perspective, Journal of Organizational Learning and Leadership, 11 (2), 1-7.

World Economic Forum (2015), 'The Global Gender Gap Report', Geneva, Switzerland: World Economic Forum. 
